\section{Congress may force drug firms to reveal clinical trial data}

Erika Check, Washington

Congressional investigators have threatened to enact laws that will make the disclosure of data from clinical trials compulsory.

At a House committee hearing on 9 September, lawmakers said that they were concerned about the way in which drug companies and the Food and Drug Administration (FDA) have handled data about the risks and benefits of the use of antidepressants in children.

Most of the data about potential risks have not been published in journals. The issue caused a furore in the summer, after the FDA demanded that drug companies provide these data and found that children who received some types of antidepressants in clinical trials were more likely to exhibit suicidal tendencies.

Representatives of seven drug companies told investigators at the hearing that they had not deliberately withheld the data. Acknowledging problems with credibility, the companies said they were taking steps to disclose more data. For example, they are participating in a voluntary clinical-trial database organized by the Pharmaceutical Research and Manufacturers Association trade group.

But some lawmakers said that this was not good enough. "I don't accept the idea of a voluntary registry," said Congressman Henry Waxman (Democrat, California) at the hearing. He asked Congress to consider requiring all companies to register clinical trials at their outset in a public database. An international group of medical journal editors announced on 8 September that it would make registration a condition of publication.

Lawmakers also criticized the FDA for stalling congressional investigations. Janet Woodcock, an FDA official, suggested that the law sometimes prevents the FDA from releasing certain information about clinical trials. But Greg Walden (Republican, Oregon) replied: "If the law is preventing you from acting, you need to tell us that, and if it's your own rules that prevent you, you need to fix them."

Concerns about the amount of information released by the FDA were echoed at a meeting of an advisory committee four days after the congressional hearing. "The FDA needs to regain respect," said Maryellen Winter, a mother whose daughter killed herself after taking the antidepressant paroxetine.

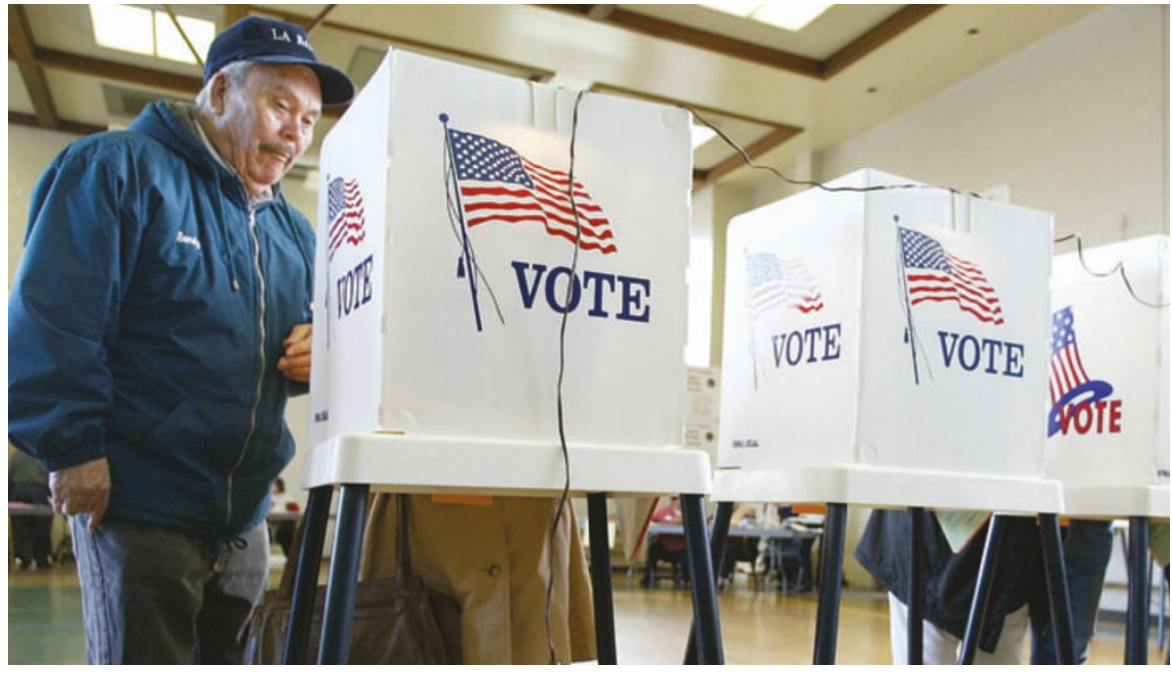

California poll: voters are split over a plan to issue $\$ 3$ billion in bonds to fund stem-cell research.

\title{
Critics slate ethical leeway in California stem-cell proposal
}

\section{Jonathan Knight, San Francisco}

Opponents of California's \$3-billion plan to fund embryonic stem-cell research say that the proposal would give researchers carte blanche to rewrite well-established ethical guidelines to suit their needs.

They say the research institute planned under the initiative will be exempt from legislative supervision and, if established, will be able to make its own rules about conflicts of interest and informed consent.

Proponents are reacting angrily to the charges, saying that the proposal provides the highest possible level of accountability and will serve as a model of how science can be funded at the state level.

The California Stem Cell Research and Cures Initiative will appear as Proposition 71 on the ballot in the elections due on 2 November. If passed, it will authorize a bond issue of nearly $\$ 3$ billion over ten years to fund embryonic stem-cell research and infrastructure. It will create the California Institute for Regenerative Medicine to distribute the funds.

But public opinion is sharply divided on the proposition, with $45 \%$ in favour and $42 \%$ opposed.A California columnist has branded it an "audacious raid on the treasury" and details of the initiative are under increased scrutiny in the run up to the election.

The institute will be run by a 29 -member Independent Citizens Oversight Committee. Although most committee members will be selected by high-ranking elected officials, including the governor and lieutenant governor, the legislature will have no power to intervene in the institute's affairs or to change the provisions of the initiative.

This could create problems because public money is involved, warns Daniel Sarewitz, an expert on science policy at Arizona State University in Tempe. "Scientists don't like the fact that the ugly democratic process has stopped them from doing certain kinds of research," he says. "This is an attempt to go around that process."

Proposition-71 backers say that in this case it is necessary to exclude the legislature to ensure that it will not misappropriate the bond fund to help balance the budget. The committee will be accountable in other ways, supporters of the proposition say, with open meetings and an annual analysis of its finances. "We have the highest possible standards of accountability," says initiative spokeswoman Fiona Hutton.

This does not reassure Diane Beeson, a medical sociologist at California State University, Hayward, who says the committee will have unrestricted freedom to rewrite the rules of informed consent. At first, these will have to be "generally based on" the standards established by the National Institutes of Health (NIH), according to the text of the initiative, but the committee will then be free to modify them as necessary.

Beeson claims that passing Proposition 71 will result in poor women lining up to donate eggs for the development of stem-cell lines, in exchange for the modest payments permitted to cover expenses.

Rex Greene, who is an oncologist and spokesman for the opposition, says that the committee will also have the power to rewrite its own conflict-of-interest guidelines, after initially basing them on NIH rules. "It's going to be a sham of peer review," he says.

Such charges are groundless, counters Irving Weissman, a stem-cell researcher at Stanford University, who helped author the measure. He promises that scientists based outside California will advise the committee on which grants to fund. "We want to avoid even the appearance of a conflict," says Weissman. 